Jurnal Kesmas Asclepius

Volume 1, Nomor 1, Juni 2019

e-ISSN : 2684-8287

p-ISSN : 2656-8926

DOI: https://doi.org/10.31539/jka.v1i1.747

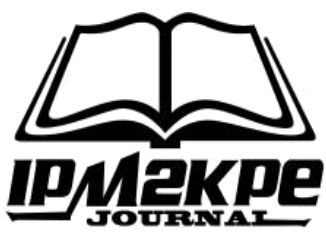

\title{
PENGARUH PENDIDIKAN KESEHATAN MEDIA VIDEO DAN POSTER TERHADAP PENGETAHUAN DAN SIKAP ANAK DALAM PENCEGAHAN PENYAKIT DIARE
}

\author{
Harsismanto $\mathbf{J}^{1}$, Eva Oktavidiati ${ }^{2}$, Dina Astuti ${ }^{3}$ \\ Universitas Muhammadiyah Bengkulu ${ }^{1,2,3}$ \\ harsis@umb.ac.id ${ }^{1}$
}

\begin{abstract}
ABSTRAK
Penelitian ini bertujuan untuk mengetahui pengaruh pendidikan kesehatan dengan media video dan poster terhadap pengetahuan dan sikap anak kelas IV SDN 65 Seluma dalam pencegahan penyakit diare. Jenis penelitian ini adalah penelitian kuantitatif dengan pendekatan quasi experiment menggunakan rancangan two group pre and post test design. Hasil penelitian menunjukkan rata-rata skor pengetahuan anak pada kelompok media video sebelum intervensi didapatkan 68.00, setelah intervensi 86.67, sikap anak sebelum intervensi didapatkan 52.67 setelah diberikan intervensi 80.93 dengan $\rho$-value 0,000 . Rata-rata skor pengetahuan pada kelompok media poster sebelum intervensi didapatkan 72.67 setelah intervensi 87.33, sikap anak sebelum intervensi adalah 42.20 setelah intervensi 65,40 dengan $\rho$-value 0,000. Simpulan, ada pengaruh yang signifikan pendidikan kesehatan menggunakan media video dan poster terhadap pengetahuan dan sikap anak dalam pencegahan penyakit diare.
\end{abstract}

Kata Kunci : Pendidikan Kesehatan, Pengetahuan, Poster, Sikap, Video

\section{ABSTRACT}

This study aims to determine the effect of health education using video and poster media on the knowledge and attitudes of fourth grade SDN 65 Seluma children in preventing diarrhea. This type of research is a quantitative study with a quasi-experimental approach using a two group pre and post test design. The results showed that the average score of children's knowledge in the video media group before the intervention was 68.00, after the intervention was 86.67, the child's attitude before the intervention was 52.67 after being given the intervention 80.93 with $\rho$-value 0.000. The average score of knowledge in the media poster group before the intervention was 72.67 after the intervention was 87.33, the attitude of the child before the intervention was 42.20 after the intervention was 65.40 with a $\rho$-value of 0.000. In conclusion, there is a significant effect of health education using video media and posters on children's knowledge and attitudes in preventing diarrhea disease.

Keywords: Health Education, Knowledge, Posters, Attitudes, Videos 


\section{PENDAHULUAN}

Anak usia sekolah adalah anak pada usia 6-12 tahun. Pada usia ini anak diharapkan memperoleh dasar-dasar pengetahuan yang dianggap penting untuk keberhasilan penyesuaian diri anak ketika dewasa kelak (Wong, 2009).

Perilaku Hidup Bersih dan Sehat (PHBS) adalah sekumpulan perilaku yang dipraktikkan atas dasar kesadaran sebagai hasil pembelajaran yang menjadikan seseorang, keluarga, kelompok atau masyarakat mampu menolong dirinya sendiri (mandiri) di bidang kesehatan dan berperan aktif dalam mewujudkan kesehatan masyarakat. PHBS dapat dilaksanakan di masyarakat, rumah tangga, dan sekolah (Kemenkes RI, 2014).

Menurut Pusat Promosi Kesehatan (PPK) Kemenkes RI (2011), PHBS di sekolah adalah sekumpulan perilaku sehat yang dipraktikkan oleh peserta didik, guru dan masyarakat lingkungan sekolah atas dasar kesadaran sebagai hasil pembelajaran, sehingga secara mandiri mampu meningkatkan kesehatan, berperan aktif dalam mewujudkan lingkungan sekolah yang sehat dan mampu mencegah penyakit. Hal ini disebabkan karena banyak data yang menunjukkan munculnya sebagian penyakit yang sering menyerang anak usia sekolah seperti diare, cacingan dan demam berdarah umumnya berasal dari sekolah (Maryunani, A. 2013).

Menurut WHO (2013), diare adalah keluarnya 3 atau lebih feses yang longgar atau cair per hari atau lebih sering daripada yang normal untuk individu. Ini biasanya merupakan gejala infeksi gastrointestinal, yang dapat disebabkan oleh berbagai organisme bakteri, virus, dan parasit. Infeksi menyebar melalui makanan atau air minum yang terkontaminasi, atau dari orang ke orang sebagai akibat dari kebersihan yang buruk.

Penyakit diare masih sering menimbulkan KLB (Kejadian Luar Biasa) dengan penderita yang banyak dalam waktu yang singkat. Rendahnya cakupan personal hygiene dan sanitasi lingkungan sering sekali menjadi faktor resiko terjadinya KLB diare (Kemenkes RI, 2011). Penyebab utama kematian akibat diare adalah dehidrasi akibat kehilangan cairan dan elektrolit melalui tinja. Penyebab kematian lainnya adalah disentri, kurang gizi, dan infeksi. Golongan usia yang paling menderita akibat diare adalah anak-anak karena daya tahan tubuhnya yang masih lemah. Pada tahun 2013 diare merupakan penyebab kematian nomor dua pada anak-anak. Sebanyak 1,7 miliar kasus diare terjadi setiap tahunnya dan menyebabkan sekitar 760.000 anak meninggal dunia setiap tahunnya (Christy, 2014). Menurut Profil Kesehatan Provinsi Bengkulu (2015) jumlah target penemuan diare di Provinsi Bengkulu sebanyak 40.124 kasus diare, sebanyak 32.849 ditangani (82\%) (Dinkes Kota Bengkulu, 2015).

Berdasarkan data yang peneliti dapat dari Puskesmas Cahaya Negeri pada tahun 2016 penemuan kasus diare sebanyak 439 dengan jumlah diae yang ditangani 65, pada tahun 2017 terdapat 287 penemuan kasus diare dengan berbagai macam umur terutaman balita dan anak-anak dari $<1$ tahun, 1-4 tahun, $>5$ tahun sampai dewasa, sedangkan pada tahun 2018 didapatkan penemuan kasus diare dari bulan Januari sampai Agustus sebanyak 195 orang.

Kurangnya kesadaran cuci tangan pada anak usia sekolah dasar menjadi penyebab masalah kesehatan, yaitu salah satunya penyakit diare, Infeksi Saluran Pernapasan Atas (ISPA), cacingan dan Flu burung. Kesadaran akan pentingnya cuci tangan pada anakanak menggunakan sabun dengan baik dan benar terbukti secara ilmiah efektif untuk mencegah penyebaran penyakit-penyakit. Oleh karena itu, anak usia sekolah dasar perlu 
mendapatkan pendidikan kesehatan, terutama tentang mencuci tangan dengan baik dan benar (Depkes, 2010).

Pendidikan kesehatan memerlukan media dalam menyampaikan materi yang akan diberikan, salah satunya menggunakan media video dan poster. Menurut Notoatmodjo (2010) media video merupakan salah satu jenis media audio visual karena media ini mengandalkan indera penglihatan dan indera pendengaran. Adapun media poster menurut Kunoli (2012) merupakan penggambaran yang ditunjukkan sebagai pemberitahuan, peringatan, maupun penggugah selera yang biasannya berisi gambargambar. Penggunaan media dalam pemberian pendidikan kesehatan akan menarik minat siswa untuk mempelajari materi yang diberikan. Media yang menarik akan memberikan keyakinan, sehingga perubahan kognitif, afektif dan psikomotor dapat dipercepat (Setiawati \& Dermawan, 2008).

Berdasarkan hasil survei awal yang dilakukan di SDN 65 Seluma pada tanggal 29 September 2018, jumlah anak kelas IV sebanyak 37 orang. Diungkapkan oleh kepala sekolah SDN 65 Seluma setiap satu bulan sekali ada promosi kesehatan di sekolah tersebut dan disana sudah terdapat UKS yang di jaga oleh guru dan dokter kecilnya. Di ungkapkan secara lisan oleh guru dan kepala sekolah SDN 65 Seluma dalam 3 bulan terakhir pernah ada anak yang sakit sehingga izin sekolah karena mengalami diare walau tidak terdata secara tertulis.

Penelitian ini bertujuan untuk melihat pengaruh pendidikan kesehatan dengan media video dan poster terhadap pengetahuan dan sikap anak kelas IV SDN 65 Seluma dalam pencegahan penyakit diare.

\section{METODE PENELITIAN}

Jenis penelitian ini adalah kuantitatif dengan menggunakan desain eksperimen. Metode eksperimen yang digunakan adalah quasi eksperiment, menggunakan rancangan two group pre and post test design. Penelitian dilakukan di SDN 65 Seluma pada tanggal 06 November-06 Desember 2018. Populasi dalam penelitian ini adalah seluruh anak kelas IV SDN 65 Seluma sebanyak 37 orang. Sampel yang digunakan dalam penelitian ini adalah seluruh anak Kelas IV sebanyak 30 orang yang dibagi menjadi dua kelompok menggunakan total sampling, sesuai dengan kriteria inklusi yaitu ; 1) Anak tercatat sebagai murid kelas IV SDN 65 Seluma; 2) Belum pernah mendapatkan pendidikan kesehatan tentang pencegahan penyakit diare secara khusus; 3) Anak yang hadir pada saat pengambilan sampel; 4) Anak yang bersedia menjadi responden.

Pengumpulan data dengan data primer yang didapatkan secara langsung menggunakan kuesioner pengetahuan dan sikap dan data sekunder yang didapat dari jumlah data anak SD kelas IV. Pelaksanaan penelitian dilakukan 3 kali pertemuan dalam 1 bulan, hari pertama peneliti melakukan pengukuran tingkat pengetahuan dan sikap sebelum dilakukan edukasi (pre test) Untuk kuesioner pengetahuannya terdiri dari 10 pertanyaan dan sikap juga terdiri dari 10 pernyataan. Pertemuan kedua barulah peneliti melakukan atau memberikan pendidikan kesehatan menggunakan media video maupun poster selama +/- 15 menit dengan keterlibatan peneliti dalam proses pemberian pendidikan kesehatan pada siswa masing-masing kelompok. Pertemuan ketiga peneliti melakukan pengukuran selanjutnya (post test) dengan kuesioner yang sama pada pretest nya. Analisis data dengan analisis univariat, uji normalitas menggunakan uji shapiro wilk dan analisis bivariat menggunakan uji t-dependent. 
HASIL PENELITIAN

Analisis Univariat

Tabel 1

Distribusi Karakteristik Responden

Berdasarkan Umur dan Jenis Kelamin

\begin{tabular}{ccccc}
\hline \multirow{2}{*}{ Karakteristik } & \multicolumn{2}{c}{ Kelompok I Media Video } & \multicolumn{2}{c}{ Kelompok II Media Poster } \\
\cline { 2 - 5 } & $n$ & $\%$ & & \\
\hline Umur ( Tahun) & & & 10 & $66.7 \%$ \\
\hline 9 & 6 & $40 \%$ & 5 & $33.3 \%$ \\
\hline 10 & 9 & $60 \%$ & 7 & $46.7 \%$ \\
\hline Jenis Kelamin & & & 8 & $53.3 \%$ \\
\hline Laki-laki & 8 & $53.3 \%$ & 15 & $100 \%$ \\
\hline Perempuan & 7 & $46.7 \%$ & &
\end{tabular}

Dari tabel 1 dapat dilihat bahwa rata-rata umur sampel 9 tahun dan 10 tahun dan berjenis kelamin laki-laki dan perempuan.

\section{Distribusi Frekuensi Tingkat Pengetahuan Anak pada Kelompok Media Video dan Poster Sebelum dan Sesudah Diberikan Intervensi}

Tabel 2

Distribusi Frekuensi Tingkat Pengetahuan Anak Pada Kelompok Pendidikan Kesehatan Menggunakan Media Video dan Poster Sebelum dan Sesudah Diberikan Intervensi

\begin{tabular}{|c|c|c|c|c|c|c|c|c|c|}
\hline \multirow[t]{3}{*}{ Variabel } & \multirow[t]{3}{*}{ Tingkat Pengetahuan } & \multicolumn{4}{|c|}{ Media Video } & \multicolumn{4}{|c|}{ Media Poster } \\
\hline & & \multicolumn{2}{|c|}{ Pre } & \multicolumn{2}{|c|}{ Post } & \multicolumn{2}{|c|}{ Pre } & \multicolumn{2}{|c|}{ Post } \\
\hline & & $n$ & $\%$ & $n$ & $\%$ & $n$ & $\%$ & $n$ & $\%$ \\
\hline \multirow[t]{4}{*}{$\begin{array}{c}\text { Pengetahua } \\
\mathrm{n}\end{array}$} & Kurang & 5 & $\begin{array}{c}33.3 \\
\%\end{array}$ & 0 & $0 \%$ & 1 & $6.7 \%$ & 0 & $0 \%$ \\
\hline & Cukup & 4 & $\begin{array}{c}26.7 \\
\%\end{array}$ & 2 & $13.3 \%$ & 6 & $\begin{array}{c}40.0 \\
\%\end{array}$ & 2 & $13.3 \%$ \\
\hline & Baik & 6 & $\begin{array}{c}40.0 \\
\%\end{array}$ & 10 & $66.7 \%$ & 8 & $\begin{array}{c}43.3 \\
\%\end{array}$ & 9 & $60.0 \%$ \\
\hline & Sangat Baik & 0 & $0 \%$ & 3 & $20.0 \%$ & 0 & $0 \%$ & 4 & $26.7 \%$ \\
\hline Total & & 15 & $\begin{array}{c}100 \\
\%\end{array}$ & 15 & $100 \%$ & 15 & $\begin{array}{c}100 \\
\%\end{array}$ & 15 & $100 \%$ \\
\hline
\end{tabular}

Berdasarkan tabel 2 dapat dilihat distribusi frekuensi tingkat pengetahuan anak sebelum diberikan intervensi pendidikan kesehatan menggunakan media video terdapat 6 orang anak $(40,0 \%)$ yang berpengetahuan baik dan setelah diberikan intervensi terdapat 10 orang anak $(66,7 \%)$ yang berpengetahuan baik. Sedangkan pada media poster sebelum diberikan intervensi terdapat 8 orang anak $(43,3 \%)$ yang berpengetahuan baik dan setelah diberikan intervesi maka didapatkan 9 orang anak (60,0\%) yang berpengetahuan baik. 


\section{Distribusi Frekuensi Sikap Anak pada Kelompok Media Video dan Media Poster Sebelum dan Sesudah Diberikan Intervensi}

Tabel 3

Distribusi Frekuensi Sikap Anak dalam Pencegahan Penyakit Diare Dengan Media Video dan Poster Sebelum dan Sesudah Diberikan Intervensi

\begin{tabular}{|c|c|c|c|c|c|c|c|c|c|}
\hline \multirow[t]{3}{*}{ Variabel } & \multirow[t]{3}{*}{ Tingkat Sikap } & \multicolumn{4}{|c|}{ Media Video } & \multicolumn{4}{|c|}{ Media Poster } \\
\hline & & \multicolumn{2}{|c|}{ Pre } & \multicolumn{2}{|c|}{ Post } & \multicolumn{2}{|c|}{ Pre } & \multicolumn{2}{|c|}{ Post } \\
\hline & & $n$ & $\%$ & $n$ & $\%$ & $n$ & $\%$ & $n$ & $\%$ \\
\hline \multirow[t]{4}{*}{ Sikap } & Sangat Tdk Setuju & 4 & $26.7 \%$ & 0 & $0 \%$ & 4 & $26.7 \%$ & 0 & $0 \%$ \\
\hline & Tidak Setuju & 5 & $33.3 \%$ & 1 & $6.7 \%$ & 7 & $46.7 \%$ & 3 & $20.0 \%$ \\
\hline & Setuju & 4 & $26.7 \%$ & 5 & $33.3 \%$ & 4 & $26.7 \%$ & 9 & $60.0 \%$ \\
\hline & Sangat Setuju & 2 & $13.3 \%$ & 9 & $60.0 \%$ & 0 & $0 \%$ & 3 & $20.0 \%$ \\
\hline Total & & 15 & $100 \%$ & 15 & $100 \%$ & 15 & $100 \%$ & 15 & $100 \%$ \\
\hline
\end{tabular}

Berdasarkan tabel 3 dapat dilihat bahwa sikap anak mengenai pencegahan diare sebelum dilakukan pendidikan kesehatan menggunakan media video didapatkan ada 4 $(26,6 \%)$ orang anak yang menyatakan setuju dan setalah diberikan intervensi didapatkan $5(33,3 \%)$ orang anak yang menyatakan setuju. Sedangkan pada media poster sebelum dilakukan intervensi didapatkan ada $4(26,7 \%)$ orang anak yang menyatakan setuju dan setelah diberikan intervensi didaptkan ada 9 orang anak $(60,0 \%)$ yang menyatakan setuju.

\section{Analisis Bivariat}

Tabel 4

Pengaruh Pendidikan Kesehatan dengan Media Video dan Poster Terhadap Pengetahuan Anak dalam Pencegahan Penyakit Diare Sebelum dan Sesudah Pemberian Pendidikan Kesehatan

\begin{tabular}{|c|c|c|c|c|c|c|c|c|}
\hline Variabel & Kelompok & $n$ & Mean & SD & Beda Mean & $\mathrm{t}$ & $p$-value & $95 \% \mathrm{Cl}$ \\
\hline \multirow[t]{5}{*}{ Pengetahuan } & Media video & & & & \multirow{4}{*}{18.67} & \multirow{3}{*}{-7.299} & \multirow{3}{*}{.000} & \multirow{3}{*}{$\begin{array}{l}13.182- \\
24.151\end{array}$} \\
\hline & Sebelum & 15 & 68.00 & 16.987 & & & & \\
\hline & Sesudah & 15 & 86.67 & 9.759 & & & & \\
\hline & Media Poster & & & & & \multirow[b]{2}{*}{-5.358} & \multirow[b]{2}{*}{.000} & \multirow{2}{*}{$\begin{array}{l}8.796- \\
20.537\end{array}$} \\
\hline & Sebelum & 15 & 72.67 & 12.228 & 14.66 & & & \\
\hline
\end{tabular}

Berdasarkan tabel 4 dapat dilihat bahwa rata-rata pengetahuan siswa sesudah diberikan intervensi dengan media video adalah 86,67 dengan standar deviasi 9,759. Sedangkan rata-rata pengetahuan anak sesudah diberikan pendidikan kesehatan dengan media poster adalah 87,33 dengan standar deviasi 10.328. Dengan $P$-value $=0,000>$ 0,05 maka hipotesis nol ditolak, yang berarti ada pengaruh signifikan Pendidikan kesehatan dengan media video dan poster terhadap pengetahuan dan sikap anak kelas IV SDN 65 Seluma dalam pencegahan penyakit diare. 
Tabel 5

Pengaruh Pendidikan Kesehatan dengan Media Video dan Poster Terhadap Sikap Anak dalam Pencegahan Penyakit Diare Sebelum dan Sesudah Diberikan Intervensi

\begin{tabular}{|c|c|c|c|c|c|c|c|c|}
\hline Variabel & Kelompok & $N$ & Mean & SD & Beda Mean & $\mathrm{t}$ & p-value & $95 \% \mathrm{Cl}$ \\
\hline \multirow{6}{*}{ Sikap } & Media video & & & & \multirow{4}{*}{28.26} & \multirow{4}{*}{-10.882} & \multirow{4}{*}{.000} & \multirow{4}{*}{$\begin{array}{c}33.838- \\
22.695\end{array}$} \\
\hline & Sebelum & 15 & 52.67 & 18.074 & & & & \\
\hline & Sesudah & 15 & 80.93 & 12.027 & & & & \\
\hline & Media Poster & & & & & & & \\
\hline & Sebelum & 15 & 42.20 & 15.162 & \multirow[t]{2}{*}{23.2} & \multirow[t]{2}{*}{-6.101} & \multirow[t]{2}{*}{.000} & \multirow{2}{*}{$\begin{array}{c}31.356- \\
15.044\end{array}$} \\
\hline & Sesudah & 15 & 65.40 & 20.458 & & & & \\
\hline
\end{tabular}

Berdasarkan tabel 5 dapat dilihat bahwa rata-rata sikap siswa sesudah diberikan intervensi media video rata-rata sikap anak menjadi 80.93 dengan standar deviasi 12.027. Sedangkan sesudah diberikan intervensi dengan media poster rata-rata sikap anak menjadi 65,40 dengan standar deviasi 20.458. Dengan $P$-value $=0,000<0,05$ maka hipotesis nol ditolak, yang berarti ada pengaruh signifikan pendidikan kesehatan dengan media video dan poster terhadap sikap anak kelas IV SDN 65 Seluma dalam pencegahan penyakit diare.

\section{PEMBAHASAN}

\section{Analisa Univariat}

\section{Pengukuran Pengetahuan Anak dengan Media Video dan Poster Sebelum dan} Sesudah Diberikan Intervensi

Berdasarkan hasil pre-test pada kelompok media video dan poster sebelum diberikan perlakuan, secara umum pengetahuan responden tentang pencegahan diare kelompok media video dan poster sudah baik. Tetapi dari informasi yang peneliti dapatkan anak SDN 65 Seluma terkhusus anak kelas IV belum mendapatkan pendidikan khusus tentang pencegahan diare selama berada di sekolah baik dari pendidikan sekolah atau dari UKS (Usaha Kesehatan Sekolah). Karena hal tersebut peneliti tertarik untuk memberikan pendidikan kesehatan kepada anak kelas IV melalui media video dan poster yang tertuangkan pesan-pesan kesehatan tentang pencegahan diare didalamnya berupa gambar dan alur cerita sebagai media pembelajaran dan inovasi pendidikan kesehatan.

Setelah diberikan perlakuan berupa pendidikan kesehatan dengan media video dan poster tentang pencegahan diare selama 3 minggu, diketahui dari hasil post-test responden adanya peningkatan yang signifikan pengetahuan responden tentang diare sebelum dan sesudah perlakuan dari pengetahua kurang dan cukup menjadi pengetahuan baik dan sangat baik. Peningkatan rata-rata skor pengetahuan pada kelompok pendidikan kesehatan dengan menggunakan media video dan poster sebelum dan sesudah intervensi menunjukkan hasil yang positif, hal ini menandakan penggunaan media dalam proses pembelajaran mempermudah anak dalam menerima pengetahuan baru, Notoatmodjo (2012) menjelaskan pemilihan media yang tepat sangat penting dalam menyampaikan informasi.

Pendidikan kesehatan memerlukan media dalam menyampaikan materi yang akan diberikan, salah satunya menggunakan media video dan poster. Menurut Notoatmodjo (2010) media video merupakan salah satu jenis media audio visual karena media ini mengandalkan indera penglihatan dan indera pendengaran. Adapun media poster menurut Kunoli (2012) merupakan penggambaran yang ditunjukkan sebagai 
pemberitahuan, peringatan, maupun penggugah selera yang biasannya berisi gambargambar. Penggunaan media dalam pemberian pendidikan kesehatan akan menarik minat siswa untuk mempelajari materi yang diberikan. Media yang menarik akan memberikan keyakinan, sehingga perubahan kognitif, afektif dan psikomotor dapat dipercepat (Setiawati \& Dermawan, 2008).

Penggunaan media yang melibatkan banyak indera akan semakin meningkatkan pemahaman terhadap suatu informasi, sehingga penggunaan media audio visual (video) berupa gambar dan video bergerak yang melibatkan indera penglihatan dan pendengaran akan membantu peserta didik dalam proses pembelajaran yang berfungsi memperjelas dan mempermudah dalam memahami informasi yang didapatkan. Penggunaan media video dirasa lebih efektif dan menarik bagi klien sehingga ketercapaian tujuan pendidikan kesehatan akan lebih optimal (Hariyadi, 2012).

Hasil penelitian ini sejalan dengan penelitian Rohana dan Arbianingsih (2016) menunjukan ada peningkatan pengetahuan tentang diare sebelum dan sesudah diberikan intervensi dengan media video pada kelompok perlakuan dan kelompok kontrol. Perubahan pengetahuan responden dipengaruhi oleh pendidikan kesehatan adalah materi yang diberikan, media pendidikan, dan sasaran diseluruh materi yang disampaikan cukup menarik yang dapat dilihat dari antusias responden dengan $P$-value $=0,000$.

Menurut Musfiqon (2012) poster memiliki kelebihan untuk menjadi media pembelajaran seperti dapat mempermudah dan mempercepat siswa terhadap pesan yang disajikan, dapat dilengkapi dengan warna-warna yang dapat menarik perhatian siswa, bentuknya sederhana tampa memelukan peralatan khusus dan mudah untuk penempatannya dan pembuatanya pun mudah dan harganya murah.

\section{Pengukuran Sikap Anak dengan Media Video dan Poster Sebelum dan Sesudah Diberikan Intervensi}

Diketahui hasil post-test pada kelompok intervensi media video setelah dilakukan intervensi rata-rata sikap anak 1 orang anak $(6,7 \%)$ yang menyatakan tidak setuju, 5 orang anak (33,3\%) yang menyatakan setuju dan 9 orang anak $(60,0 \%)$ yang menyatakan sangat setuju dan pada kelompok intervensi media poster setelah lakukan intervensi rata-rata 3 orang anak $(20,0 \%)$ yang menyatakan tidak setuju, 9 orang anak $(60,0 \%)$ yang menyatakan setuju dan 3 orang anak $(20,0 \%)$ yang menyatakan sangat setuju. Ada peningkatan yang signifikan terhadap sikap responden tentang diare sebelum dan sesudah perlakuan dari pernyatan sikap sangat tidak setuju dan tidak setuju menjadi setuju dan sangat setuju.

Hasil penelitian ini sejalan dengan penelitian sebelumnya Tarigan (2016) yang bejudul " Efektifitas promosi kesehatan dengan media leaflet dan video tehadap pengetahuan dan sikap remaja tentang HIV/AIDS di SMA Negeri I Berastagi tahun 2016" Hasil penelitian menunjukkan bahwa sikap remaja baik setelah mendapatkan penyuluhan. Pengetahuan remaja tentang HIV/AIDS, setelah diberikan intervensi promosi kesehatan dengan media leaflet mengalami peningkatan dari kurang menjadi cukup dan sikap dari cukup menjadi baik. Sedangkan media video mengalami peningkatan dari kurang menjadi baik dan sikap dari cukup menjadi baik dengan $P$ value $=0,000$.

Untuk penelitian ini dapat di simpulkan bahwa ada peningkatan sebelum dan sesudah diberikan intervensi terhadap sikap anak dalam pencegahan penyakit diare baik dengan media video maupun media poster. Notoatmodjo (2012) menjelaskan bahwa fokus utama pemberian pendidikan kesehatan adalah perubahan perilaku. Senada 
dengan penjelasan Nursalam \& Efendi (2008) menjelaskan tujuan pendidikan kesehatan adalah perubahan perilaku, dengan tujuan spesifik yaitu perubahan pengetahuan (kognitif), sikap (pengertian, motivasi), atau praktik (mendapatkan akses informasi kesehatan, mempergunakan informasi) untuk meningkatkan atau mempertahankan kesehatannnya. Adapun salah satu determinan pembentukan sikap seseorang menurut Sunaryo (2013) yaitu komunikasi sosial berupa informasi yang diterima oleh individu tersebut. Informasi yang diberikan kepada responden berupa pemberian edukasi kesehatan dengan menggunakan media pendidikan yang tepat akan meningkatkan pengetahuan serta pemahaman siswa tentang pencegahan diare, yang pada akhirnya akan meningkatkan sikap siswa usia sekolah dalam pencegahan diare dengan rutin cuci tangan pakai sabun.

\section{Analisa Bivariat}

Pengaruh Pendidikan Kesehatan dengan Media Video terhadap Pengetahuan Anak dalam Pencegahan Penyakit Diare Sebelum dan Sesudah Intervensi

Berdasakan data distribusi didapatkan bahwa rata-rata pengetahuan anak sebelum diberikan pendidikan kesehatan dengan media video rata-rata pengetahuan anak sebeulm diberikan intervensi adalah 68.00 dengan standar deviasi 16,987, setelah diberikan intervensi dengan media video rata-rata pengetahuan anak menjadi 86,67 dengan standar deviasi 9,759. Sedangkan untuk rata-rata sikap anak sebelum diberikan intervensi media video adalah 52.67 dengan standar deviasi 18.074.

Hasil penelitian ini sejalan dengan penelitian Imran \& Hasnah (2017) menunjukkan bahwa ada peningkatan pengetahuan remaja kelas X SMAN 2 GOW sesudah diberikan penyukuhan melalui media video dengan $p$-value $=0,000$. Berdasakan hasil yang diperoleh, media video ini adalah salah satu media yang efektif digunakan dalam penyuluhan kesehatan.

Menurut Agustina. (2012) media video memiliki beberapa manfaat sebagai berikut: membantu memberikan kesan yang benar, mendorong minat anak dalam proses pembelajaran, meningkatkan pengertian yang lebih baik, menambah variasi metode mengajar, meningkatkan keingintahuan anak sehingga membuat anak lebih kritis terhadap pembelajaran, dan memberikan konsep baru dari sesuatu di luar pengalaman yang biasa.

\section{Pengaruh Pendidikan Kesehatan dengan Media Video terhadap Sikap Anak dalam Pencegahan Penyakit Diare Sebelum dan Sesudah Intervensi}

Berdasakan data distribusi didapatkan bahwa rata-rata sikap anak sebelum diberikan pendidikan kesehatan dengan media video setelah diberikan intervensi media video rata-rata sikap anak menjadi 80.93 dengan standar deviasi 12.027. Karena pengetahuan dan sikap anak dengan $\mathrm{p}$-Value $=0,000>0,05$, maka berarti ada pengaruh signifikan pendidikan kesehatan dengan media video dan poster terhadap pengetahuan dan sikap anak kelas IV SDN 65 Seluma dalam pencegahan penyakit diare.

Hasil Penelitian ini sejalan dengan penelitian Luluq (2014), yang berjudul "Pengaruh penyuluhan kesehatan dengan media video terhadap pengetahuan dan sikap personal hygiene siswa SD Negeri I kepek pengasih kulon progo", dengan hasil yang didapatkan ada pengaruh penyuluhan tentang dengan media video terhadap pengetahuan dan sikap personal hygiene dengan $P$-value $=0,000$. 
Pemberian edukasi media video terhadap sikap dipengaruhi oleh beberapa faktor yaitu : pengalaman pribadi, pengaruh kebudayaan, media massa, lembaga pendidikan dan lembaga agama dan faktor emosional.

Pengaruh Pendidikan Kesehatan dengan Media Poster terhadap Pengetahuan Anak dalam Pencegahan Penyakit Diare Sebelum dan Sesudah Diberikan Intervensi

Berdasarkan distribusi dapat dilihat bahwa rata-rata pengetahuan dan anak sebelum dan sesudah diberikan pendidikan kesehatan dengan media poster. Rata-rata pengetahuan anak sebelum di berikan intervensi media poster adalah 72.67 dengan standar deviasi 12.228, setelah diberikan interrvensi rata-rata pengetahuan anak menjadi 87,33 dengan standar deviasi 10.328 .

Hasil penelitian ini sejalan dengan penelitian sebelum yang diteliti oleh Linasari (2017) yang berjudul "Pengaruh penggunakan media poster dan leaflet terhadap pengetahuan siswa SMA di Bandar Lampung tentang karies gigi" dengan hasil ada pengaruh pendidikan dengan media poster terhadap pengetahuan tentang karies gigi dengan $p$-value $=0,000$.

Menurut Notoatmojo (2010) faktor-faktor yang mempengaruhi pengetahuan diantaranya; pendidikan, media massa / informasi, sosial budaya dan ekonomi, lingkungan dan pengalaman.

\section{Pengaruh Pendidikan Kesehatan dengan Media Poster terhadap Sikap Anak dalam Pencegahan Penyakit Diare Sebelum dan Sesudah Diberikan Intervensi}

Berdasarkan distribusi dapat dilihat bahwa rata-rata sikap dan anak sebelum dan sesudah diberikan pendidikan kesehatan dengan media poster. Rata-rata sikap sebelum diberikan intervensi dengan media poster adalah 42,20 dengan standar deviasi 15,162, setelah diberikan intervensi dengam media poster rata-rata sikap anak menjadi 65,40 dengan standar deviasi 20,458. Dengan $\mathrm{p}$ Value $=0,000<0,05$ yang berarti ada pengaruh signifikan pendidikan kesehatan dengan media poster terhadap sikap anak kelas IV SDN 65 Seluma dalam pencegahan penyakit diare.

Menurut Musfiqon (2012) poster yang baik memiliki ciri-ciri yaitu sederhana, menyajikan satu ide dan untuk mencapai satu tujuan pokok, berwarna, slogannya, tulisannya yang jelas, motif dan tulisannya bervariasi. Dari ciri-ciri tersebut poster memiliki kelebihan untuk menjadi media pembelajaran seperti dapat mempermudah dan mempercepat siswa terhadap pesan yang di sajikan, dapat dilengkapi dengan warnawarna yang dapat menarik perhatian siswa, bentuknya sederhana tampa memerlukan peralatan khusus dan mudah untuk penempatannya dan pembuatanya pun mudah dan harganya murah.

Pemberian edukasi media poster terhadap sikap dipengaruhi oleh beberapa faktor yaitu pengalaman pribadi, pengaruh kebudayaan, media massa, lembaga pendidikan dan lembaga agama dan faktor emosional.

\section{SIMPULAN}

Dari hasil penelitian dapat disimpulkan ada pengaruh secara signifikan pendidikan kesehatan menggunakan media video dan poster terhadap pengetahuan dan sikap anak kelas IV SDN 65 Seluma dalam pencegahan diare. 


\section{SARAN}

Menerapkan pentingnya menjaga kebersihan diri, lingkungan dan makanan sesudah dan sebelumnya harus mencuci tangan pada anak kelas IV SDN 65 Seluma dalam pencegahan penyakit diare. Mengingatkan dan memberi fasilitas yang layak untuk digunakan oleh anak-anak dalam hidup bersih dan sehat.

\section{DAFTAR PUSTAKA}

Agustina, E. (2012). Hubungan antara Tingkat Pengetahuan tentang Fluor Albus (Keputihan) dengan Cara Penanganan Keputihan pada Siswi SMP Gunung Jati Kembaran. STIKES Harapan Bangsa

Christy, M. Y. (2014). Faktor yang Berhubungan dengan Kejadian Dehidrasi Diare pada Balita di Wilayah Kerja Puskesmas Kalijudan. Jurnal Berkala Epidemiologi, 2(3), 297-308

Depkes. (2010). Pedoman Nasional Tumbuh Kembang Anak. Jakarta: Gramedia

Dinkes Kota Bengkulu. (2015). Profil kesehatan Propinsi 2015, Bengkulu: Dinkes Kota

Hariyadi, H. (2012). Modul Video sebagai Media Layanan Bimbingan dan Konseling Semarang : Sigit Hariyadi Press

Imran, F. A., \& Hasnah, H. (2017). Pengaruh Penyuluhan Kesehatan Melalui Media Video terhadap Peningkatan Pengetahuan Remaja Putri tentang Dampak Abortus Provokatus Kriminalis di Kelas X SMAN 2 Gowa. Jurnal JF FKIK UINAM, 2: 61-67

Kemenkes RI. (2011). Panduan Sosialisasi Tatalaksanan Diare pada Balita. Jakarta: Direktorat Jendral Pengendalian Penyakit dan Penyehatan Lingkungan

Kemenkes RI. (2014). Profil Kesehatan Indonesia. Jakarta: Kementrian Kesehatan Republik Indonesia, 2014

Kunoli, J. F. (2012). Asuhan Keperawatan Penyakit Tropis. Jakarta: CV. Trans Info Media

Linasari, L. (2017). Pengaruh Penggunaan Media Poster dan Leaflet terhadap Pengetahuan Siswa SMA di Bandar Lampung tentang Karies Gigi. Jurnal Keperawatan, XIII (1): $103-109$

Luluq, E. (2014). Pengaruh Penyuluhan Kesehatan dengan Media Video terhadap Pengetahuan dan Sikap Personal Hygiene Siswa SD Negeri 1 Kepek Pengasih Kulon Progo. Sekolah Tinggi Ilmu Kesehatan 'Aisyiyah Yogyakarta

Maryunani, A. (2013). Perilaku Hidup Bersih dan Sehat. Jakarta: Trans Info Media

Musfiqon, M. (2012). Pengembangan Media dan Sumber Media Pembelajaran. Jakarta: PT. Prestasi Pustakaraya

Notoatmodjo, S. (2010). Ilmu Perilaku Kesehatan. Jakarta : PT Rineka Cipta

Notoatmodjo, S. (2012). Promosi Kesehatan dan Perilaku Kesehatan, Edisi Revisi.Jakarta : Rhineka Cipta

Nursalam, N., \& Efendi, F. (2008). Pendidikan dalam Keperawatan.Jakarta: Salemba

Rohana, R., \& Arbianingsih, A. (2016). Pengaruh Pendidikan Kesehatan dengan Media Video terhadap Pengetahuan Anak Pra Sekolah tentang Pencegahan Penyakit Diare di TK Minasaupa. Jurnal Wawasan Keislaman Sulesana, 10 (1)

Setiawati, S., \& Dermawan, A. C. (2008). Proses Pembelajaran dalam Pendidikan Kesehatan. Jakarta: Trans Info Media

Tarigan, E. R.(2016). Efektivitas Promosi Kesehatan dengan Media Leaflet dan Video terhadap Pengetahuan dan Sikap Remaja tentang HIV/AIDS di SMA Negeri 1 Berastagi Tahun 2016. Skripsi. Medan 
2019. Jurnal Kesmas Asclepius 1 (1) 75-85

WHO. (2013). https://www.who.int/ topics/diarrhoea/en/. Diakses pada tanggal 30 maret 2019

Wong, W. (2009). Buku Ajar Keperawatan Pedriatik. Cetakan pertama. Jakarta: EGC 